Claude A. Trépanicr MD, FRCPC, Claude Brousseau MD, FRCPC, Louise Lacerte MD

\title{
Myalgia in outpatient surgery: comparison of atracurium and succinylcholine
}

We siudied 60 outpatients randomly divided into two groups. Anesthesia was induced with fentanyl $1.5 \mu \mathrm{g} \cdot \mathrm{kg}^{-1}$ plus thiopentone $5-7 \mathrm{mg} \cdot \mathrm{kg}^{-1}$. Patients in Group I were intubated with the aid of succinylcholine $1.5 \mathrm{mg} \cdot \mathrm{kg}^{-1}$ after pre-treatment with d-rubocurarine $0.05 \mathrm{mg} \cdot \mathrm{kg}^{-1}$. Group II received atracurium $350 \mu \mathrm{g} \cdot \mathrm{kg}^{-1}$ three minutes after a priming dose of $50 \mu \mathrm{g} \cdot \mathrm{kg}^{-1}$. Anesthesia was maintained with isoflurane $1-2$ per cent in a mixlure of nitrous axide 60 per cent and oxygen 40 per cent. No supplemental doses of fentanyl or atracurium were given. Intubation conditions were satisfactory for all patients in both groups. There was no significant difference in intubation score between the two groups. The incidence of myaigia was 76 per cent in the succinylcholine group compared to 23 per cent in the atracurium group ( $p<0.0005)$. Fiffy per cent of the patients in the succinyicholine group had myalgia necessitating bed rest or analgesics compared to 23 per cent in the atracurium group $(p<0.05)$. We conclude that atracurium is a suitable neuramuscular relaxant for outpatient surgery and that myalgia is a major morbidity factor in this population that can be reduced by the use of atracurium instead of succinylcholine.

The popularity of outpatient surgery has been increasing in the last two decades, mostly because of cost-containment efforts. Brindle reviewed the complications of outpatient surgery and found myalgias to be the most frequent (45 per cent). 'Succinylcholine is a well known cause of muscle pain and multiple strategies have been attempted to decrease the incidence of this annoying complication (self-taming, ${ }^{2}$ lidocaine, ${ }^{3}$ small-dose of nondepolarizing agent). ${ }^{4-6}$ However, myalgia remains one of the most frequent complication of outpatient surgery.

\section{Key words}

NEUROMUSCULAR RELAXANTS: sUccinylcholine, atracurium; SURGERY: outpatient; INTUB ATION: tracheal; COMPLICATIONS: myalgia.

From the Department of Anesthesia, Hốpital de l'Enfant-Jésus. Université Laval, 1401, 18e rue, Québec, Qc, GIJ 1 Z4. Address correspondence to: Dr. Trépanier.
Atracurium is a new non-depolarizing neuromuscular blocking agent which, according to Gyasi, is a suitable alternative for short procedures. ${ }^{7}$ Our hypothesis was that atracurium, being a non-depolarizing agent should be associated with a lower incidence of postoperative myalgia in day surgery patients. Our study was designed to verify both this hypothesis and Gyasi's conclusions about conditions of intubation with atracurium.

\section{Methods}

The protocol was approved by the Hospital Ethics Committee and informed, written consent was obtained from all patients. Sixty patients aged between 17 and 59 undergoing a day surgery procedure, requiring tracheal intubation, were studied. All were ASA physical status class I or II, free of neuromuscular disease and none were taking any medication known to interfere with neuromuscular function. Patients undergoing an operation requiring a tourniquet were excluded from the study.

An intravenous infusion of lactated Ringer's solution in five per cent dextrose was established prior to induction. The ECG was monitored continuously and arterial blood pressure monitored by an electronic oscillometer (Dinamapp). Neuromuscular blockade was assessed by observation of thumb adduction, using a Bard peripheral nerve stimulator applying supramaximal stimuli to the ulnar nerve at the wrist via surface electrodes. Train-offour (TOF) stimuli of $2 \mathrm{msec}$ duration and 2 hertz frequency produced every 12 seconds were used throughout the study. The assessment of the response was made by visual observation only, reproducing the usual clinical conditions.

The patients were divided in two groups by tandom allocation. They did not receive any premedication and in both groups anaesthesia was induced with fentanyl 1.5 $\mu \mathrm{g} \cdot \mathrm{kg}^{-1}$, followed by thiopentone $5-7 \mathrm{mg} \cdot \mathrm{kg}^{-1}$ intravenously. Group 1 , the control group, received d-tubocurarine $0.05 \mathrm{mg} \cdot \mathrm{kg}^{-1}$ followed three minutes later by succinylcholine $1.5 \mathrm{mg} \cdot \mathrm{kg}^{-1} .{ }^{8}$ Group II, the study group, received atracurium $350 \mu \mathrm{g} \cdot \mathrm{kg}^{-1}$ three minutes after a priming dose of $50 \mu \mathrm{g}^{\circ} \mathrm{kg}^{-1}$. Following induction, anaesthesia was maintained with 60 per cent nitrous oxide 
TABLE I Scoring system for intubating conditions

\begin{tabular}{ll} 
Score & Conditions \\
\hline 4 & $\begin{array}{l}\text { Cords abducted, jaw well-relaxed, optimum intubating } \\
\text { conditions }\end{array}$ \\
3 & $\begin{array}{l}\text { No muscular response to intubation but jaw not totally relaxed } \\
\text { andror cords not totally abducted }\end{array}$ \\
2 & $\begin{array}{l}\text { Poor jaw relaxation, slight cough, contraction of diaphragm, } \\
\text { cords nol abducted }\end{array}$ \\
1 & $\begin{array}{l}\text { Vigorous cough, contraction of the diaphragm and trink } \\
\text { muscles, jaw not relaxed, cords not abducted }\end{array}$ \\
0 & Unable to intubate because of poor relaxation
\end{tabular}

"From Blitt C.D. et al. ${ }^{11}$

in oxygen, supplemented with isoflurane one to two per cent, inspired. No supplemental dose of atracurium or fentanyl was given in either group. Ventilation was controlled using an Ohio V5A ventilator and a Bain circuit, adjusted to maintain normocarbia. ${ }^{10}$ Neuromuscular blockade was reversed with neostigmine 0.04 $\mathrm{mg} \cdot \mathrm{kg}^{-1}$ and glycopyrrolatc $0.012 \mathrm{mg} \mathrm{kg}^{-1}$, at the end of the procedure if necessary. Time zero was taken as the beginning of the induction (either injection of d-tubucurarine or the priming dose of atracurium).

The investigator in charge of the anaesthetic evaluated intubating conditions using the Blitt scale ${ }^{11}$ (Table I). All patients were telephoned 24 and 48 hrs postoperatively by a physician who was unaware of the relaxant the patient had received. They were questioned on many aspects of their surgery and anaesthesia, including myalgia, without however, emphasizing the latter. In order to evaluate the intensity of the post-operative muscle pain with objective criterias, we elaborated a scale according to its severity (Table II). In a second part of the study, we submitted to the same questionnaire a group of 24 outpatients undergoing very short procedures not necessitating intubation and who did not receive any muscle rclaxant.

Statistical analysis was performed using the Chi square test with the Maentel-Haentzel formula, for intubating

\section{TABLE II Myalgia scale}

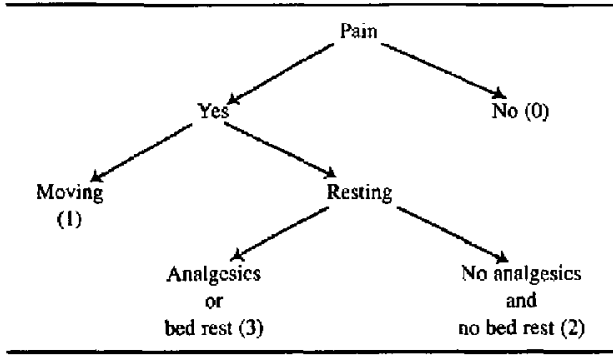

TABLE III Results (study groups)

\begin{tabular}{lllll}
\hline & $\begin{array}{l}\text { Succinyl- } \\
\text { choline } \\
\text { group }\end{array}$ & \% & $\begin{array}{l}\text { Alracurium } \\
\text { group }\end{array}$ & \% \\
\hline Patients & 26 & & 34 & \\
Female & 19 & 73.1 & 25 & 73.5 \\
Male & 7 & 26.9 & 9 & 26.5 \\
Age (mean) & 35 & & 35 & \\
Age (range) & $17-57$ & & $15-49$ & \\
& & & & \\
Type of surgery & & & & 23.5 \\
ENT & 5 & 19.2 & 8 & 41.2 \\
Gynaecologic & 12 & 46.2 & 14 & 17.7 \\
Orthopaedic & 5 & 19.2 & 6 & 17.7 \\
Plastic & 4 & 15.4 & 6 & \\
\hline
\end{tabular}

conditions and myalgias scores, and by Student's t test for analysis of induction time. Differences were considered significant when $\mathrm{p}<0.05$. Results are expressed as means $\pm \mathrm{SD}$.

\section{Results}

There was no difference between the two groups with respect to age, sex, body weight, and type of surgery (Table III). The incidence of the other minor complications (nausea, vomiting and sore throat) was comparable in the two groups. Intubating conditions were satisfactory for all patients in both groups (intubating score of two or more) (Figure). There was no significant difference in intubating score between the two groups. Tracheal intubation was easily performed in all patients. Induction time was $297 \pm 80$ seconds in Group I and $379 \pm 89$ seconds in Group II, a difference of one minute twenty-two seconds ( $p<0.005$ ). In Group II, neuromuscular blockade was easily reversed at the end of the procedure, when necessary, and all patients were extubated without any problem.

The incidence of myalgia was 76 per cent in the succinylcholine group compared with 23 per cent in the atracurium group ( $\mathrm{p}<0.0005$ ) (Table IV) and 20.8 per cent in the group which did not receive a muscle relaxant. 50 per cent of the patients in the succinylcholine group had myalgia necessitating bed rest or analgesies compared to 23 per cent in the atracurium group ( $p<0.05$ ). Moreover, if we add the class 2 patients (pain without movement) to class 3 patients, a figure that represents the most affected patients, the number becomes 73 vs $23 \mathrm{per}$ cent $(p<0.005)$.

\section{Discussion}

Many factors have been implicated as sources of postoperative myalgia. We tried to control either by a standard 


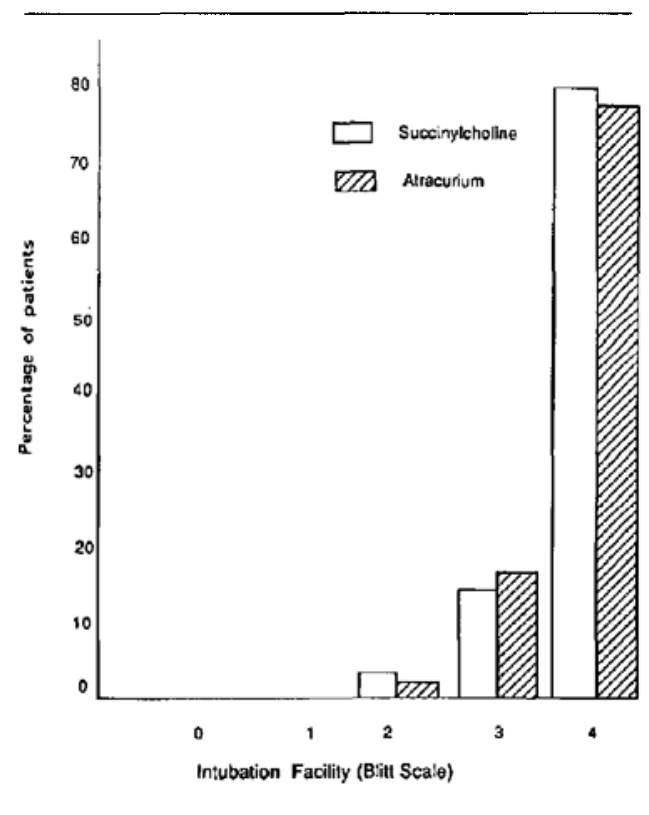

FIGURE Intubating Scores. See Table I for Scoring System.

technique or randomization the following variables which are mentioned in the literature as possible causative factors: sex, ${ }^{12}$ age, ${ }^{13}$ dose of succinylcholine administered, ${ }^{14}$ type of operation, ${ }^{15}$ positioning of the patient, ${ }^{16}$ intubation as cause of neck myalgia and mobilization after the operation. ${ }^{17}$

The incidence of post-operative myalgia is remarkably variable in published studies ( 1.5 to 89 per cent) ${ }^{1,2,5,6,11}$ Our incidence of 76.4 per cent in the succinylcholine group is at the higher range of previously reported values.

TABLE IV Results (myalgia)

\begin{tabular}{lllll}
\hline & $\begin{array}{l}\text { Succinyl- } \\
\text { choline } \\
\text { group }\end{array}$ & $\%$ & $\begin{array}{l}\text { Atracurius } \\
\text { group }\end{array}$ & $\%$ \\
\hline Patients & 26 & & 34 & \\
myalgia" & 20 & 76.9 & 8 & 23.5 \\
Myalgia score & & & & \\
0 & 6 & 23.1 & 26 & 76.5 \\
1 & 1 & 3.8 & 0 & \\
2 & 6 & 23.1 & 0 & 23.5 \\
$3 \dagger$ & 13 & 50.0 & 8 & \\
\hline
\end{tabular}

$* p<0.00005$

$\dagger p<0.05$.

Scote 2 and 3 patients combined $(p<0.005)$.
These differences can be explained by many factors in addition to those mentioned above: different populations, nature of the questionaire, number of days of the survey, ${ }^{6}$ aggressivity of the interrogator. Our study demonstrates that myalgia is a very frequent complication in our outpatient population and that it can be reduced significantly by the use of atracurium. Furthermore, we also found that 50 per cent of the patients receiving succinylcholine had to stay in bed or take an analgesic because of severe myalgia compared with 23 per cent in the group receiving atracurium. Myalgia is not only a frequent complication but also a debilitating one.

One can wonder why patients in the atracurium group experienced myalgia. It appears that there is a nonreducible incidence of muscle pain that is probably not related to the muscle relaxant. In the second part of the study, we found an incidence of myalgia of 20.8 per cent, in a group of patients undergoing very short procedures and who did not receive any muscle relaxant. This incidence is about the same as in the atracurium group. We can conclude that there is a basic incidence of myalgia that seems to be unrelated to the use of muscle relaxant.

Our data on intubating conditions are in agreement with Gyasi's finding: none of the patients had poor conditions for intubation. A limitation of this aspect of our study is its single-blind nature, but assessing intubating conditions was not our main objective and we were mostly confirming data from a previous double-blind study. The difference of one minute twenty-two seconds for induction time between the two groups might have been longer if we had not used a priming dose, but this is still a controversial issue ${ }^{18,19}$

In summary, this study confirms that atracurium is a suitable relaxant for short outpatient surgery. Furthermore, myalgia is a major morbidity factor in our population that can be significantly reduced by the use of atracurium for tracheal intubation instead of succinylcholine. The small drawback related to the use of atracurium is a slightly longer induction period.

\section{References}

1 Brindle G, Soliman MG. Anaesthetic complications in surgical outpatients. Can Anaesth Soc J 1975; 22: 613-9.

2 Verma RS. "Self-taming" with succinylcholine and muscle pain. Anesthesiology 1983; 58: 487.

3 Miller RD, Way WL. Inhibition of succinylcholine increased intragastric pressure by nondepolarizing muscle relaxant and lidocaine. Anesthesiology 1971; 34: 185-8.

4 Brodsky JB, Brock-Utne JB, Samuets SL. Pancuronium pre-treatment and post-succinylcholine myalgias. Anesthesiology 1979; 51: 259-61.

5 Bennets FE, Khalil KI. Reduction of post-suxamethonium 
pain by pretreatment with four non-depolarizing agents. $\mathrm{Br} J$ Anaesth 1981; 53: 531-6.

6 Manani G. Valenti S, Segatto A, Angel M, Meroni M Giron GP. The influence of thiopentone and alfathesin on succinylcholine-induced fasciculations and myalgias. Can Anaesth Soc J 1981; 28: 253-7.

7 Gyasi HK, Naguib NM, Adu-GyamfiY, Atracurium for short surgical procedures: a comparison with succinylcholine. Can Anaesth Soc J 1985; 32: 613-7.

8 Horrow $J L$, Lambert $D H$. The search for an optimal interval between pretreatment dose of d-tubocurarine and succinylcholine. Can Anaesth Soc J 1984; 31: 528-33.

9 Naguib M. Aldullatif $M$. Absoud GH. The optimal priming dose for atracurium. Can Anaesth $S \propto \mathrm{J}$ 1986; 33: 453-7.

10 Bain $J A$, Spoerel WE. Flow requirements for a modified Mapleson D system during controlled ventilation. Can Anaesth Soc J 1980; 20: 629-36.

11 Blitt CD, Charison BL, Rolling GD, Hameroff $S R$, Ono $C W$. A comparative evaluation of pretreatment with nondepolarizing neuromuscular blockers prior to the administration of succinylcholine. Anesthesiology 1981; 55; 687-9.

12 Hegarity $P$. Postoperative muscle pains. Br J Anaesth 1956; 28: $209-12$.

13 Burrles $R$. Muscle pains afier suxamethonium and suxcthonium. Br J Anaesth $1961 ; 33: 147-50$.

14 Lamoreaux $L F$, Urbach $K F$. Incidence and prevention of muscle pain following the administration of succinylcholine. Anesthesiology 1960; 21: 394-6.

15 Datta S, Corcker IS. Alper MH. Muscle pain following administration of suxamethonium to pregnant and nonpregnant patients undergoing laparoscopic tubal ligation. $\mathrm{Br}$ J Anaesth 1977; 49: 625-8.

16 Crawford JS. Suxamethonium muscle pains and pregnancy. Br J Angesth 1971; 43: 677-80.

17 Bryson THL, Ormston TOG. Muscle pains following the use of suxamethonium in caesarean section. Br J Anaesth $1962 ; 34 ; 476-9$.

18 Sosis $M$, Larijani GE, Marr Al. Priming with atracurium Anesth Analg 1987; 66: 329-32.

19 Ramsey FM, Ramsey FM, Weeks DB, Morell RC, Gerr $P$. The priming principle ineffectiveness of atracurium pretreatment. Anesthesiology 1985; 63: A341.

\section{Résumé}

Nous avons érudie 60 patients en chirurgie d' un jour attribués de façon aléatoire à deux groupes. L'anesthésie fut induite avec du fentanyl $1.5 \mu \mathrm{g} \cdot \mathrm{kg}^{-1}$ et du shiopental $5-7 \mathrm{mg} \cdot \mathrm{kg}^{-1}$. Les patients du groupe I furent insubés avec de la succinylcholine 1.5 $m g \cdot \mathrm{kg}^{-1}$ précédée de d-tubocurarine $0.05 \mathrm{mg} \cdot \mathrm{kg}^{-1}$ et ceux du groupe II avec de l'atracurium $350 \mu \mathrm{gg}^{-\mathrm{kg}^{-1}}$ apres une dose $d^{\prime}$ amorçage de $50 \mu \mathrm{g} \cdot \mathrm{kg}^{-1}$. Le maintien de l'anesthésie contsistait d" isoflurane 1-2 pour cent dans un mélange de protoxide d'azote 60 pour cent et oxygène 40 pour certr. Aucun supplément de fentanyl ou d' atracurium ne fut administré. Les conditions d'intubation furent satisfaisantes pour tous tes patients. $/ 1 n^{\prime} y$ avait pas de différence significative entre les deux groupes. $L$ 'incidence des myalgies fut de 76 pour cent dans le groupe succinylcholine compare d 23 pour cent pour l'atracurium (p $<$ $0.0005 ;$. De plus, 50 pour cent des patients ayant reçu de la succinylcholine durent garder le lit ou prendre des analgésiques contre 23 pour cent avec l'atracurium $(p<0.05)$. Nous concluons que l'atracurium est une alternative valable contme relaxant ent chirurgie d' un jour et que les myalgies représentent une source importante de morbidité que peut ètre atténuée par l'emploi d' auracurium. 